\title{
IMPLEMENTASI DIGITAL LEADERSHIP DALAM PENGEMBANGAN KOMPETENSI DIGITAL PADA PELAYANAN PUBLIK
}

\section{DIGITAL LEADERSHIP IMPLEMENTATION IN DEVELOPING DIGITAL COMPETENCY IN PUBLIC SERVICES}

\author{
Farida Dwi Cahyarini \\ Pusat Pendidikan dan Pelatihan Pegawai - Balitbang SDM Kemkominfo \\ Jalan Raya Kelapa Dua No. 49D, Kota Jakarta Barat \\ fari006@kominfo.go.id \\ Diterima tgl. 19/02/2021; Direvisi tgl. 05/05/2021; Disetujui tgl. 07/05/2021
}

\begin{abstract}
In today's digital age, organization leaders must develop their leadership capacity according to the needs and demands of the community, especially in public services. This research aims to analyse the implemention of digital leadership which is expected to be one of the keys in the development of digital competencies of public services Radio Frequency Spectrum License at the Directorate of Spectrum Licensing, Directorate General of Resources Management and Equipment of Posts and Informatics/Ditjen SDPPI. The research method used is case study, with research data collection techniques using literature studies derived from documents, reports, books, scientific journals relevant to this research. Analysis techniques used are data analysis techniques and SWOT analysis. The results explain that with implementing digital leadership, encourage the maximum utilization of information technology, thereby resulting in a meaningful improvement of digital-based public services, which is reflected in various achievements. Although all indicators have satisfied service users, there is still hope of better service improvement in certain areas. Therefore, this Service Unit must response by improving its public services in the future with the development of digital competencies of service officers in accordance with the standards of position competency in a planned, orderly and measurable.
\end{abstract}

Keywords: Digital leadership, Digital Competency Development, Public Service

\begin{abstract}
ABSTRAK
Pada era digital seperti saat ini pemimpin organisasi harus mengembangkan kapasitas kepemimpinannya sesuai kebutuhan dan tuntutan masyarakat, utamanya dalam pelayanan publik. Penelitian ini bertujuan untuk menganalisis implementasi kepemimpinan digital yang diharapkan menjadi salah satu kunci dalam pengembangan kompetensi digital pelayanan publik perizinan Spektrum Frekuensi Radio pada Direktorat Operasi Sumber Daya Ditjen SDPPI. Metode penelitian yang digunakan adalah studi kasus, dengan teknik pengumpulan data penelitian menggunakan studi literatur yang berasal dari dokumen, laporan, buku-buku, jurnal ilmiah yang relevan dengan penelitian ini. Teknik analisis yang digunakan adalah teknik analisis data dan analisis SWOT. Hasil penelitian menjelaskan bahwa dengan implementasi kepemimpinan digital mendorong pemanfaatan teknologi informasi yang maksimal sehingga menghasilkan perbaikan pelayanan publik berbasis digital, yang tercermin dari berbagai capaian prestasi. Walaupun semua indikator sudah memuaskan pengguna layanan, masih terdapat harapan perbaikan pelayanan yang lebih baik pada bidangbidang tertentu sehingga Unit Layanan ini harus menjawab dengan meningkatkan layanan publiknya di masamasa yang akan datang dengan pengembangan kompetensi digital petugas pelayanan sesuai standar kompetensi jabatan secara terencana dan terukur.
\end{abstract}

Kata Kunci: Digital leadership, pengembangan kompetensi digital, pelayanan publik

\section{PENDAHULUAN}

\subsection{Latar Belakang}

Sejak awal sikap pemerintah telah mengusung perlunya digitalisasi. Presiden Jokowi dalam pemaparan program pemerintahan mengatakan bahwa Indonesia membutuhkan pemerintahan "Dilan". Dilan yang dimaksud adalah kependekan dari 'Digital Melayani', yaitu reformasi pelayanan publik lewat elektronik. Selain itu, juga diperlukan penajaman dan penyederhanaan 
kelembagaan serta peningkatan kualitas SDM aparatur dan reformasi tata kelola. Yang namanya pelayanan bukan hanya melayani, tetapi kecepatan itu sangat diperlukan sehingga reformasi dalam bidang pelayanan lewat layanan yang berbasis elektronik merupakan keniscayaan.

Pemerintah selalu berusaha mengupayakan birokrasi yang bersih dengan didukung oleh proses tatakelola yang efisien dan efektif serta sumber daya manusia (SDM) aparatur yang berkualitas. Tantangan besar yang dihadapi birokrasi adalah bagaimana mereka mampu melaksanakan kegiatan secara efisien dan efektif (Cordella \& Tempini, 2015). Kualitas pelayanan publik merupakan salah satu sorotan yang diarahkan kepada birokrasi pemerintah dengan masih seringnya muncul tanda pagar (tagar) berita yang menyoroti tentang pelayanan publik pemerintah. Sebagai contoh, pada publikasi oleh Researchgate dengan judul Mengurus Perizinan Usaha di Indonesia: Mudah atau Sulit? di tingkat ASEAN daya saing kemudahan berbisnis Indonesia masih tertinggal (Indonesia Peringkat Kelima Terendah di Asean, 2019).

Penelitian ini membahas pelayanan perizinan Spektrum Frekuensi radio dengan jumlah pengguna ratusan ribu. Berdasarkan Undang-undang Nomor 36 Tahun 1999 Tentang Telekomunikasi, penggunaan spektrum frekuensi radio dan orbit satelit wajib mendapatkan ijin dari pemerintah dengan memperhatikan perlindungan kepentingan dan keamanan negara. Oleh karena itu, diperlukan pemimpin digital (digital leadership) yang bersedia dan mampu berkomunikasi dengan cara, saluran, dan alat baru dengan penekanan lebih besar pada bagaimana berpikir kritis, komunikatif, dan kolaborasi secara terintegrasi. Seperti pendapat ahli, kemajuan digital telah membentuk konsep kepemimpinan gaya baru yang dapat membawa generasi yang berbeda untuk bekerja bersama-sama (Narbona, 2016).

Studi terdahulu meneliti tentang pemimpin organisasi dalam era disrupsi yang harus menemukan metode untuk selalu mengembangkan kapasitas kepemimpinannya (Hoerudin, 2020). Kepemimpinan pada era digital fokus pada pola kepemimpinan yang melakukan banyak inovasi kebijakan, pemimpin yang dinamis dan mampu memanfaatkan posisinya dalam memimpin untuk melakukan perubahan, berupa inovasi yang berbasis teknologi serta meningkatkan kualitas dan kompetensi anggotanya untuk mencapai tujuan organisasi dengan cara komunikasi yang efektif, berkolaborasi, dan kuat berkoordinasi.

Berdasarkan latar belakang permasalahan tersebut, kajian dalam penelitian ini fokus pada berbagai persoalan, yaitu 1) proses perijinan yang tersendat dikarenakan kurangnya pemahaman persyaratan dan prosedur oleh petugas; 2) manajemen belum sepenuhnya meng-upgrade sistem, 3) belum adanya pengaturan waktu pelayanan di luar jam kerja, 4) belum ada tracking penyelesaian pengaduan, 5) roadmap pengembangan kompetensi SDM belum tersedia. Adapun tujuan penelitian ini adalah membawa para pembaca untuk mendapat gambaran nyata implementasi kepemimpinan digital dengan mendorong pemanfaatan teknologi informasi yang maksimal dengan perbaikan pelayanan publik berbasis digital sehingga menghasilkan berbagai capaian prestasi dan dapat memenuhi ekspektasi kepuasanan masyarakat yang dilayaninya.

\subsection{Landasan Teoritis/Konsep}

a) Pelayanan Publik

Pemerintah Indonesia telah melengkapi beberapa regulasi terkait pelayanan publik, yaitu Undang-Undang Nomor 25 Tahun 2009 tentang Pelayanan Publik yang mengatur tentang prinsipprinsip pelayanan publik yang dilakukan oleh pemerintah atau korporasi yang efektif dan dapat memperkuat demokrasi serta hak asasi manusia. Selanjutnya, dari Undang-Undang tersebut dijabarkan dalam Peraturan Pemerintah Nomor 96 Tahun 2012 tentang Pelaksanaan Undangundang Nomor 25 Tahun 2009. Pada saat ini masyarakat makin menginginkan layanan publik yang 
diterimanya tepat waktu, murah, transparan dan akuntabel karena masyarakat sudah makin pintar dan dengan kemajuan teknologi digital semakin mudah masyarakat memperoleh informasi.

Dalam upaya peningkatan pelayanan kepada publik biasanya terdapat berbagai hambatan, misalnya, motivasi, keterbukaan pelayanan, dan etos kerja pegawai (Dronamraju, 2018). Kepedulian dari masyarakat terhadap pelayanan publik merupakan partisipasi dan kontrol masyarakat terhadap kualitas pelayanan publik. Tuntutan masyarakat akan pelayanan publik yang cepat, transparan, dan akuntabel menjadikan pemerintah perlu terus berupaya meningkatkan kualitas pelayanannya. Berbagai upaya pemerintah dalam hal pelayanan publik antara lain pelayanan publik perizinan spektrum frekuensi radio perlu didukung oleh proses digitalisasi yang terkait dengan 1) sistem, 2) infrastruktur, 3) bisnis proses, 4) kelembagaan, dan 5) pengembangan kompetensi SDM. Di samping hal tersebut, implementasi kepemimpinan digital merupakan keniscayaan yang harus dwujudkan.

b) Digitisasi, Digitalisasi, dan Transformasi Digital

Proses digitalisasi dimulai dari digitisasi. Digitisasi (digitizing) dalam bahasa Inggris merupakan terminologi yang dipakai dalam menjelaskan proses konversi dari bentuk cetak, video maupun audio menjadi bentuk digital. Dalam prosesnya, digitisasi memerlukan waktu, tenaga, biaya, dan menuntut adanya tenaga ahli yang menguasai tekniknya, sedangkan proses digitalisasi merupakan proses selanjutnya setelah digitisasi. Aplikasi digital saat ini sudah mengubah hampir semua sektor dengan menghadirkan model bisnis baru, memperkenalkan produk dan layanan yang inovatif, dan pada akhirnya mengubah cara negara-negara diseluruh dunia memanfaatkan teknologi digital pada semua sektor. Hal ini perlu kebijakan dan peraturan yang sesuai (Guemazi, Boutheina \& Bogdan-Martin, Doreen (2020)

Menurut Ismail (2020), Indonesia saat ini sudah berada pada tahap digitalisasi dengan sudah memanfaatkan teknologi informasi dan komunikasi dengan proses bisnis dalam meraih keuntungan dari konten yang telah terdigitasi. Pada institusi-institusi saat ini telah mengimplementasikan digitalisasi, misalnya, tata naskah dinas secara online, learning management system (LMS), online/distance learning. Pada era digital seperti saat ini diperlukan pemimpin yang dinamis dan banyak melakukan inovasi berbasis teknologi digital, berarti pemikirannya juga harus mengarah pada digital (Hoerudin, 2020).

Transformasi digital terjadi setelah tahap digitasi dan digitalisasi dilalui. Implementasi digitalisasi antara lain adalah pemanfaatkan Artificial Intelligence (AI) dan big data untuk percepatan perizinan, demand forecasting/inventory planning dalam rantai produksi, dan untuk pengambilan keputusan. Pemimpin memegang peranan penting karena transformasi digital merupakan transformasi organisasi yang efisiensi, produktivitas, kualitas pelayanan menjadi target utama organisasi.

\section{c) Digital Leadership}

Dalam rangka mencapai tujuan organisasi pada era digital seperti saat ini, banyak aspek dalam pemenuhannya, di antaranya adalah unsur kepemimpinan atau pemimpin yang berpikiran digital. Karena kesuksesan suatu organisasi tidak hanya diukur pada kinerja para staf atau personilnya saja, yang terpenting pada faktor kompetensi pemimpin organisasi. Diperlukan gaya kepemimpinan baru yang memiliki keterampilan kewirausahaan (Kazim, 2019), bahkan diperlukan sifat kepemimpinan digital yang dinamis untuk mendorong transformasi digital (Oberer,B,\& Erkollar, 2018). Selain keahlian teknis, keahlian soft skill sangat diperlukan dalam kepemimpinan digital yang dirumuskan kedalam tujuh pilar pendukung digital leadership sebagai berikut: 

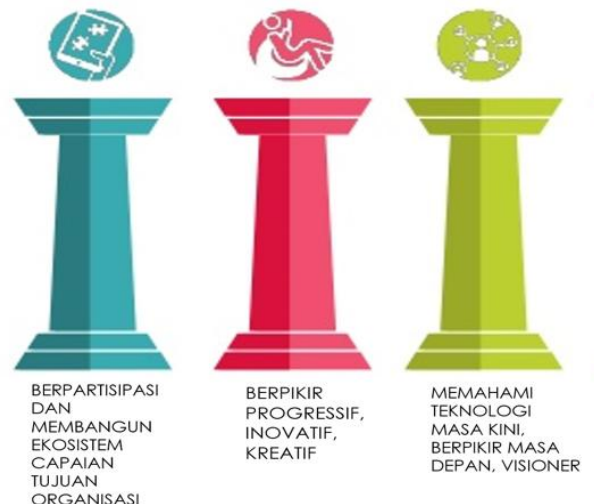

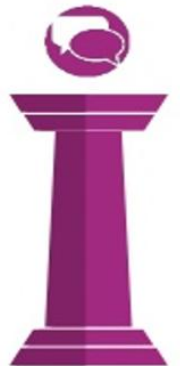

MEMBANGUN KOMUNIKAS
EFEKTIF
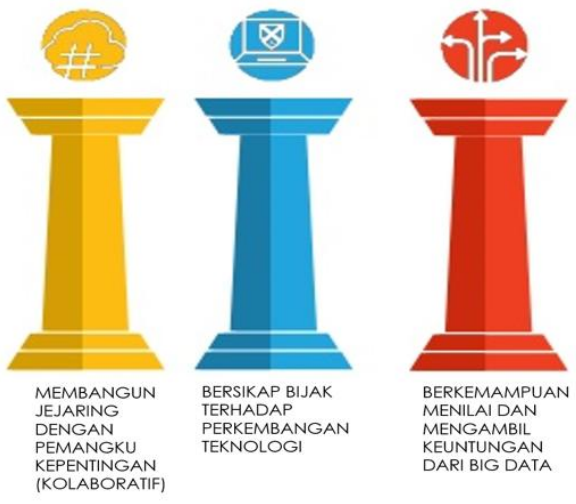

Sumber: Bahan Digital Leadership PKN I

Gambar 1. Tujuh Pilar Pendukung Digital Leadership

Dari tujuh pilar tersebut di atas, tergambar bagaimana soft skill mendominasi karakteristik kepemimpinan digital. Seorang digital leadership perlu melangkah lebih jauh dan berpandangan lebih luas, serta mampu membawa pemikiran personil yang dipimpinnya bersama-sama melintas batas bangsa, negara, geografis, budaya, dan batasan lainnya dengan memanfaatkan teknologi informasi dan komunikasi untuk mencapai tujuan organisasi, kinerja organisasi, dan pelayanan publik yang lebih baik.

Karakteristik yang diperlukan pemimpin digital atau digital leadership menurut Klein (2020):

1. Characteristics-Digital Business, yaitu seorang digital leadership harus mempunyai karakteristik Innovative visionary yang tidak cukup hanya pemikiran jauh ke depan, tetapi juga mempunyai inovasi. Karakteristik penting lainnya adalah networking intelligence, seorang digital leader harus mampu mengoordinasikan antara pengetahuan, skill, dan sumber daya tim. Tidak kalah penting bahwa seorang digital leader harus bertindak sebagai digital talent scout. Diharapkan juga mempunyai karakteristik complexity master, yaitu seorang digital leader harus bisa memahami situasi yang rumit dan bisa memecahkan masalah pada situasi yang sulit. Di samping itu terdapat karakteristik yang penting lainnya, yaitu business intelligence dalam rangka membangun model bisnis baru.

2. Characteristic-Social Attitude, yaitu seorang digital leader bertindak sebagai motivating coach, sebagai motivator dan menjadi seorang role model bagi anggota tim atau personilnya. Hal lain untuk karakteristik digital leadership adalah gaya democratic delegative, merancang organisasinya dengan hierarki dan birokrasi yang minimalis sehingga seorang digital leadership berorientasi pada personil dan fokus pada perkembangan dan kemajuan personilnya. Tidak kalah pentingnya adalah karakteristik openness yang mempunyai sifat transparansi.

3. Characteristics-General Mindset, selain karakteristik di atas terdapat karakteristik umum, yaitu agile mudah beradaptasi dengan model bisnis baru dan mampu membuat strategi transformation strategies. Hal menarik dari karakteristik digital leader adalah kemampuan untuk learning by errors dan belajar dari kesalahan merupakan hal yang penting untuk melangkah lebih baik. Karakteristik penting lainnya dari seorang digital leader adalah mempunyai knowledge-oriented dan life-long learner, keinginan terus belajar

Lebih lanjut keterampilan yang diperlukan bagi seorang digital leader, menurut Kevin Olp dari Digital Workplace Group mengutip (Sullivan, 2017): 
1. Digital Literacy, merupakan pengetahuan dan kecakapan menggunakan media digital dan teknologi informasi serta internet. Tidak hanya membutuhkan keterampilan teknis, tapi juga keterampilan kognitif, kritis, dan kreatif.

2. Digital Vision, kemampuan untuk memprediksi dan meyakinkan orang lain akan peluang jangka panjang dari teknologi baru dan meyiapkan strategi digital.

3. Defense, yaitu kemampuan pemimpin digital untuk menentukan kondisi yang dibutuhkan oleh organisasi. Pertahanan akan memotivasi SDM untuk menuju visi digital. Komitmen pemimpin untuk meningkatkan literasinya sendiri mendorong orang lain untuk mengikutinya.

4. Presence, yaitu kehadiran pemimpin merupakan bentuk anjuran yang nyata dan dapat dipraktikkan. Pemimpin dapat memiliki visi digital yang jelas dan dapat menjelaskan dengan baik tetapi, jika tidak terlihat oleh stafnya, tidak ada yang akan mengikutinya.

5. Communication, merupakan cara komunikasi pemimpin dalam mendukung kekuatan pesan yang disampaikan. Penting untuk memikirkan bagaimana cara komunikasi yang dapat mendukung visi digital.

6. Adaptability, merupakan aspek adaptasi yang paling menantang bagi para pemimpin adalah memberikan toleransi terhadap inovasi.

7. Self-Awareness, merupakan pendekatan pemimpin dan proses mempengaruhi orang lain harus berlangsung secara alami dan berkelanjutan.

8. Cultural Awareness, yaitu kesadaran budaya adalah cerminan dari visi digital. Para pemimpin harus memahami dan mengingatkan akan perbedaan budaya yang mungkin timbul dengan mengingat kepekaan cara kerja digital dalam proses komunikasi dan partisipasi.

d) Kompetensi Digital

Kompetensi digital merupakan kemampuan untuk mengeksplorasi dalam menghadapi situasi teknologi baru untuk menganalisis, memilih, mengevaluasi data dan informasi untuk memanfaatkan potensi teknologi guna memecahkan masalah (Gallardo \& Minelli de Oliveira, 2015). Aspek-aspek yang tercakup dalam kompetensi digital lebih luas dan komprehensif jika dibandingkan dengan keterampilan digital, yaitu mencakup aspek teknis yang berkaitan dengan manajemen hardware dan sofware. Konsep tersebut bergantung pada sekelompok pilar dasar seperti informasi, komunikasi, keamanan, pembuatan konten, dan pemecahan masalah (Jarad \& Shaalan, 2020). Pada masa digital seperti saat ini para anggota atau karyawan sudah harus memiliki kompetensi digital, walau tingkat dasar. The European Commision's memilah komponen kompetensi digital menjadi beberapa area: 1) Informasi dan data literasi, 2) Komunikasi dan kolaborasi, 3) Kreasi pembuatan konten digital, 4) Keamanan, dan 5) Pemecahan masalah. Mengingat keberhasilan organisasi sangat tergantung pada kualitas sumber daya manusianya, organisasi sangat mengandalkan anggotanya yang kompeten sebagai kekuatan organisasi.

\subsection{Kerangka Pemikiran}

Kerangka pemikiran dalam penelitian ini dijelaskan garis besar alur logika berjalannya penelitian dengan tujuan untuk menggambarkan hubungan antara variable yang diteliti dan diamati yaitu adanya fenomena tuntutan masyarakat akan pelayanan prima dan kebijakan pemerintah mengupayakan reformasi birokrasi yang bersih dengan dukungan proses tata kelola yang efisien dan efektif yang dilakukan oleh sumber daya manusia (SDM) aparatur yang berkualitas dan memenuhi kompetensi. Dengan demikian, perlu diterapkan kepemimpinan digital guna mendukung pelayanan perizinan frekuensi radio dengan sistem, tata kelola, kelembagaan, proses bisnis serta pengembangan kompetensi SDM aparatur. Adapun gambaran kerangka pemikiran hubungan antar variable adalah sebagai berikut. 


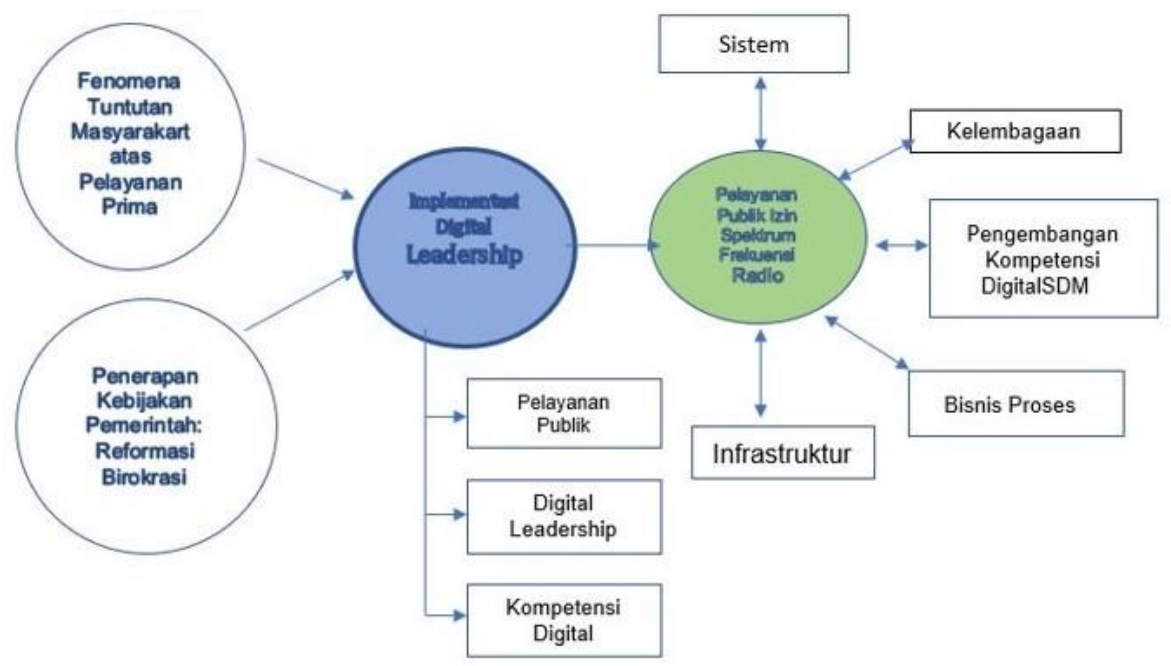

Gambar 2. Kerangka Pemikiran

\section{METODE PENELITIAN}

Penelitian ini fokus pada implementasi digital leadership yang terkait dengan inovasi pelayanan publik dan pengembangan kompetensi SDM aparatur yang terkait pelayanan publik. Analisis implementasi digital leadership pada penelitian ini diarahkan untuk melihat sejauh mana unit organisasi dari pimpinan tersebut melaksanakan tugasnya sehingga berhasil dan mencapai tujuan utamanya dalam meningkatkan pelayanan publik.

Sesuai dengan tujuan penelitian yaitu untuk memberi jawaban dan pandangan dengan mendiskripsikan suatu proses dan hasil terkait implementasi digital leadership dalam pengembangan kompetensi digital pada pelayanan publik, penelitian ini menggunakan pendekatan penelitian kualitatif dengan prosedur penelitian yang menghasilkan data deskriptif berupa kata-kata tertulis atau lisan dari informan yang diamati (Moleong, 2017). Adapun tempat penelitian ini adalah Direktorat Operasi Sumber Daya Direktorat Jenderal Sumber Daya dan Perangkat Pos dan Informatika Kemkominfo.

Penelitian ini menggunakan pendekatan penelitian kualitatif dengan metode studi kasus dengan pertimbangan penelitian ini akan mengekplorasi dan memfokuskan pada objek tertentu. Menurut John W. (2017), penelitian studi kasus merupakan pendekatan kualitatif karena peneliti mengeksplorasi keadaan dan posisi suatu peristiwa yang sedang berlangsung saat ini. Lebih lanjut Rahardjo (2017) menyatakan bahwa terdapat lima tahapan untuk melaksanakan penelitian dengan metode studi kasus: a) Memilih tema, topik dan kasus, b) Kasus atau beberapa kasus diidentifikasi oleh peneliti. Setelah peneliti memperoleh kasus, peneliti mengumpulkan literatur, c) Terakhir merumuskan masalah penelitian. Hal ini penting karena selain peneliti fokus pada suatu permasalahan, juga dari rumusan tersebut dapat digali informasi penting lainnya, d) Pengumpulan data, dalam penelitian studi kasus terdapat beberapa teknik pengumpulan data, yaitu wawancara, focus group discussion (FGD), dan observasi. e) Pada tahap akhir, peneliti mengolah data dan melaporkan hasil penelitian sebagai bentuk pertanggungjawaban penelitian.

Pengumpulan data dalam penelitian ini dilakukan dengan review dokumen dan informasi dari berbagai media elektronik. Dokumen yang direview antara lain: 1) Laporan Akuntabilitas Kinerja Pemerintah (LAKIP 2019) Direktorat Jenderal SDPPI, 2) Hasil Survey Lembaga Independen (LPPM IPB 2019), 3) Hasil Focus Group DiscussionI FGD) Pelayanan Publik SFR, 4) Dokumen dan data-data Laporan Tahunan Ditjen SDPPI 2019. Selain itu, juga dilakukan observasi data, mengidentifikasi dan mengkaji berbagai laporan yang relevan, studi dokumentasi dan wawancara 
dengan objek penelitian yaitu informan yang relevan dalam menjawab rumusan masalah penelitian ini. Adapun informan tersebut adalah Direktur Operasi Sumber Daya dan para ASN yang menjabat sebagai Koordinator dan Subkoordinator yang berjumlah lima orang dan bertugas pada pelayanan publik perizinan spektrum frekuensi radio pada Ditjen SDPPI Kemkominfo. Adapun parameternya adalah inovasi sistem, baik infrastruktur maupun bisnis proses pelayanan publik dan pengembangan kompetensi digital bagi para ASN pada unit yang terkait pelayanan. Adapun teknik analisis yang digunakan dalam penelitian ini adalah menggunakan teknik analisis data dan analisis SWOT yang sering digunakan dalam penelitian yang bersifat pembahasan mendalam dari data-data yang tersedia. Dengan teknik analisis ini, akan dilakukan pemetaan data kekuatan dan kelemahan yang merupakan posisi dari peran internal serta peluang tantangan dari eksternal (Gurel \& TAT, 2017). Analisis SWOT dapat menemukan hasil analisis dari empat sisi yang berbeda, di antaranya (1) bagaimana kekuatan (strength) mampu memperoleh manfaat dari sebuah peluang (opportunities) yang ada, (2) bagaimana cara mengatasi kelemahan (weakness) yang mencegah perolehan manfaat, (3) bagaimana kekuatan (strengths) mampu menghadapi ancaman (threats) yang ada, dan (4) bagaimana cara mengatasi kelemahan (weakness) yang mampu membuat ancaman (threats) menjadi nyata atau menciptakan ancaman baru (Setiadi et al., 2020).

\section{HASIL DAN PEMBAHASAN}

Pencapaian target kinerja organisasi tentu tidak terlepas dari pimpinan yang berkolaborasi dengan anggotanya dalam mencapai target dan tujuan organisasi. Pencapaian target kinerja pada lokus penelitian ini yaitu Direktorat Jenderal SDPPI tahun 2019 dan terkait pelayanan publik yang tertuang didalam LAKIP 2019 dan hasil survei oleh lembaga independen, yaitu LPPM IPB. Capaian-capaian yang terkait dengan pelayanan publik yang merupakan implementasi digital leadership pada pelayanan publik pada lokus penelitian adalah (1) Implementasi digital leadership pada pelayanan perizinan publik; (2) Penerapan kebijakan pemerintah dalam kerangka reformasi birokrasi, dan (3) Transformasi digital pada pelayanan publik spektrum frekuensi radio.

\subsection{Implementasi Digital Leadership Pada Pelayanan Perizinan Publik}

Langkah-langkah yang telah dilakukan dalam upaya percepatan pelayanan perijinan SFR:

1. Pemenuhan target tambahan spektrum frekuensi radio sebesar $350 \mathrm{MHz}$ untuk mobile broadband. Target ini tertuang dalam dokumen Rencana Strategis (Renstra) Kementerian Komunikasi dan Informatika Tahun 2015-2019. Pemenuhan target ini dapat diperoleh melalui berbagai metode, yaitu seleksi pita frekuensi radio yang dilaksanakan melalui mekanisme lelang, penataan ulang pita frekuensi radio (refarming), realokasi pengguna pita frekuensi radio, pemanfaatan pita frekuensi radio berbasis izin kelas, dan penerapan kebijakan netral teknologi.

2. Peningkatan pelayanan perizinan SFR: a) Perijinan amatir radio secara online melalui $e$ licensing untuk mempermudah dan mempercepat pelayanan kepada masyarakat, b) Percepatan perijinan SFR yang semula 21 hari menjadi One Day Service, c) Online Single Submission (OSS), d) Tanda tangan digital pada SFR, d) Tanda tangan digital pada SFR merupakan terobosan untuk mempercepat pelayanan kepada publik, pengguna layanan dapat mengunduh sendiri izin asli dalam bentuk elektronik (format file pdf) yang telah dilengkapi tanda tangan digital, e) Perizinan Jemput Bola untuk nelayan mengingat banyaknya gangguan spektrum frekuensi karena banyak kapal nelayan menggunakan spektrum frekuensi radio dengan tidak sesuai ketentuan. 
Pelayanan Penerimaan Negara Bukan Pajak (PNBP) Spektrum Frekuensi Radio merupakan sumber daya yang sangat penting, sehingga institusi ini berusaha agar sumber daya yang terbatas ini dapat menghasilkan manfaat yang semaksimal mungkin untuk masyarakat. Hasil perolehan PNBP yang bersumber dari perizinan frekuensi radio tercatat selalu bertambah dari tahun ke tahun yang disetor langsung ke kas negara untuk dapat dimanfaatkan bagi program pemerintah lainnya. Di bawah ini perolehan PNBP khusus Izin Frekuensi Radio sebagai berikut:

Tabel 1. Capaian Pendapatan Negara Bukan Pajak dari Izin stasiun Frekuensi Radio

\begin{tabular}{ccccc}
\hline No & Target & Tahun & Capaian/Realisasi & Persentase \\
\hline 1. & 13.027 .784 .508 & 2017 & 16.759 .916 .056 & $128,65 \%$ \\
2. & 14.634 .476 .271 & 2018 & 16.567 .404 .199 & $113,21 \%$ \\
3. & 14.884 .464 .000 & 2019 & 17.794 .362 .000 & $119,55 \%$ \\
\hline
\end{tabular}

Sumber: Hasil survey LPPM IPB pada Ditjen SDPPI 2019

Untuk mempermudah dan menjamin transparansi kepada publik dalam proses pembayaran PNBP yang dilakukan setahun sekali, telah disediakan pelayanan pembayaran secara host to host antar bank persepsi yang telah ditetapkan oleh Menteri Keuangan.

\subsection{Penerapan Kebijakan Pemerintah: Reformasi Birokrasi}

Menurut sumber dari unit kerja dalam rangka melaksanakan peningkatan kualitas pelayanan, terus dlakukan upaya-upaya perbaikan antara lain melakukan pengukuran melalui survei eksternal kepada pengguna layanan publik dengan salah satu indikator keberhasilannya adalah Indeks Kepuasan Masyarakat (IKM) dan Indeks Integritas Pelayanan Publik (IIPP) sesuai pedoman Permen PAN-RB Nomor 14 Tahun 2017:

a) Indeks Kepuasan Masyarakat (IKM) Pelayanan Publik

Pada penelitian ini penulis fokus pada hasil survei yang dilakukan pihak LPPM IPB tersebut pada tahun 2019 khususnya pada izin Penggunaan Spektrum Frekuensi Radio secara online dengan hasil:

Tabel 2: IKM Pelayanan Publik Ditjen SDPPI Tahun 2019

\begin{tabular}{llrc}
\hline No & \multicolumn{1}{c}{ Jenis Layanan } & \multicolumn{2}{c}{ IKM } \\
& & Skala 1-4 & Skala 25-100 \\
\cline { 3 - 4 } 1. & Perizinan Spektrum Frekuensi Radio & 3.53 & 88.15 \\
2. & Sertifikasi Operator Radio & 3.69 & 92.25 \\
3. & Pengujian Alat Perangkat Telekomunikasi & 3.45 & 86.25 \\
4. & Sertifikasi Alat dan Perangkat Telekomunikasi & 3.43 & 85.75 \\
\hline \multicolumn{2}{c}{ Total } & 3.53 & 88.15 \\
\hline
\end{tabular}

Sumber: Hasil survey LPPM IPB pada Ditjen SDPPI 2019

Nilai Indeks Kepuasan Masyarakat (IKM) secara keseluruhan sebesar 3.53 (berada pada 1-4) atau 88.15 (skala 25-100). Nilai IKM tersebut menunjukkan bahwa kinerja pelayanan yang diselenggarakan oleh Ditjen SDPPI dikatagorikan "sangat baik". Namun, penulis dapati fakta yang menunjukkan bahwa walaupun sebagian besar indikator bernilai sangat baik, pengguna layanan publik khususnya layanan izin SFR berharap adanya peningkatan terhadap kualitas waktu pelayanan dan penanganan pengaduan melalui call center yang kurang responsif terhadap pengaduan yang dilakukan oleh pengguna layanan. 
b) Indeks Integritas Pelayanan Publik (IIPP)

Indeks Integritas Pelayanan Publik (IIPP) merupakan gambaran tingkat konsistensi pejabat/petugas unit layanan publik dalam melaksanakan atau menerapkan perundang-undangan, kepatuhan pada prosedur dan kode etik unit layanan tersebut dalam memberikan pelayanan kepada masyarakat. Dari dokumen yang penulis peroleh dari unit pelayanan Ditjen SDPPI bahwa IIPP mengacu pada standar integritas yang digunakan oleh Komisi Pemberantasan Korupsi (KPK).

IIPP Tahun 2019 pada Ditjen SDPPI dilakukan pada tiga pihak yaitu eksternal, internal, dan pakar dengan indikator sebagai berikut:

1. Pihak eksternal: terdiri atas indikator Transparasi, Sistem Anti Korupsi dan Integritas Pegawai.

2. Pihak internal: terdiri atas Budaya Organisasi, Sistem Anti Korupsi, Pengelolaan SDM dan Pengelolaan Anggaran

3. Pakar: indikatornya adalah Transparasi dan Sistem Anti Korupsi.

Hasil survei IIPP tahun 2019 pada unit layanan Ditjen SDPPI sebagai berikut.

Tabel 3. Nilai IIPP Ditjen SDPPI Tahun 2019

\begin{tabular}{|c|c|c|c|}
\hline NO & Responden & Indikator & IIPP \\
\hline \multirow[t]{4}{*}{1} & Eksternal & Transparansi & 7,77 \\
\hline & & Sistem Anti Korupsi & 8,01 \\
\hline & & Integritas Pegawai & 8,27 \\
\hline & zsternal & & 8,02 \\
\hline \multirow[t]{5}{*}{2} & Internal & Budaya Organisasi & 8,26 \\
\hline & & Anti Korupsi & 8,25 \\
\hline & & Pengelolaan SDM & 7,86 \\
\hline & & Pengelolaan Anggaran & 8,09 \\
\hline & ernal & & 8,12 \\
\hline \multirow[t]{4}{*}{3} & Pakar & Transparansi & 9,25 \\
\hline & & Sistem Anti Korupsi & 8,13 \\
\hline & & IIPP Pakar & 8,70 \\
\hline & & itjen SDPPI & 8,28 \\
\hline
\end{tabular}

Sumber: Hasil survey LPPM IPB pada Ditjen SDPPI 2019

Dengan memperhatikan capaian nilai IIPP secara keseluruhan pelayanan Ditjen SDPPI, tidak ada lagi permasalahan yang dinilai negatif terjadi pada unit layanan publik yang menjadi obyek survei.

c) Predikat Wilayah Bebas Korupsi (WBK) dan Wilayah Birokrasi Bersih dan Melayani

Lokus penelitian pada Direktorat Operasi Sumber Daya merupakan satker pertama dilingkungan Kementerian Kominfo yang mendapatkan predikat Wilayah Bebas dari Korupsi (WBK) dalam pembangunan Zona Intergritas (ZI) dari Kementerian PAN \& RB. 


\subsection{Transformasi Digital pada Pelayanan Publik Spektrum Frekuensi Radio}

Dalam rangka mewujudkan transformasi digital pada pelayanan publik, unit pelayanan ini telah merancang rumusan transformasi digital yang terdiri atas:

1. Insfrastruktur dan perizinan menjadi faktor utama terselenggaranya pelayanan publik dan terintegrasi dalam SIMS (Sistem Informasi Manajemen Spektrum) yang dievaluasi secara periodik dan dilakukan penyesuaian sejalan dengan update business process atau regulasi untuk mendukung peningkatan pelayanan publik.

2. Bisnis proses dan regulasi dituangkan dalam Standar Operasional Prosedur (SOP) sebagai rujukan bagi petugas pelayanan dan pengguna layanan. Selain itu, otomatisasi bisnis proses diterapkan secara elektronik melalui SIMS.

3. Tata Kelola dan kelembagaan mengacu pada Sistem Pengelolaan Spektrum Frekuensi Radio Nasional.

4. Customer Engagement dan Inovasi, layanan kepada masyarakat telah dilengkapi dengan contact center, pusat layanan terpadu, sistem antrian online, sarana konsultasi dan pengaduan.

5. Pengembangan Kompetensi Digital ASN pada Pelayanan Publik. Pengembangan kompetensi pegawai baik yang bertugas di front-end dan back-end dilaksanakan sesuai kebutuhan dan kualifikasi skill yang berbeda. Berbagai training, team building, bimbingan teknis dilakukan secara rutin termasuk pada saat terjadi perubahan regulasi atau kebijakan.

\subsection{Tantangan dan dukungan dalam implementasi digital leadership dalam pengembangan kompetensi digital pada pelayanan publik Ditjen SDPPI}

Studi ini mengidentifikasi masih adanya kendala-kendala yang dihadapi pimpinan dan institusi dalam implementasi digital leadership, baik yang bersumber dari internal maupun eksternal, Kendala-kendala tersebut antara lain:

a. Masih kurangnya internalisasi pemahaman persyaratan dan prosedur bagi petugas pelayanan. Hal ini disebabkan perubahan teknologi demikian cepat sehingga persyaratan teknis bisa cepat berubah.

b. Manajemen belum sepenuhnya meng upgrade system. Pada era digital saat ini seyogyanya system telah dimodifikasi agar user friendly dan beralih versi mobile application.

c. Belum ada roadmap pengembangan skill petugas. Pelatihan, training, dan workshop telah sering dilaksanakan untuk para sumber daya manusia pada unit layanan, tetapi masih bersifat sporadis dan belum terencana dan terukur dengan baik

d. Perlu antisipasi terhadap keamanan dan validitas data pengguna frekuensi

Walaupun masih banyak kendala yang dihadapi, masih ada dukungan dan kesempatan yang terbuka luas dalam mewujudkan implementasi digital leadership pada pelayanan publik perizinan spektrum frekuensi radio, yaitu:

a. Pemimpin mempunyai literasi digital yang matang dan pengalaman serta pemahaman mengenai teknologi digital dengan terpenuhinya capaian-capaian pelayanan spektrum frekuensi.

b. Tersedia visi dan strategi digital untuk masa yang akan datang dan tersedia pemetaan maturitas pelayanan digital menuju transformasi digital.

c. Pemimpin selalu mengutamakan komunikasi dan kolaborasi dalam memecahkan permasalahan dan pencapaian target serta berpartisipasi membangun ekosistem dalam mencapai tujuan organisasi.

d. Dukungan anggaran yang memadai dari Penerimaan Negara Bukan Pajak 


\subsection{Analisis SWOT}

Analisis SWOT (Strength, Weakness, Opportunities, dan Threats) merupakan metode yang sistematis dalam melakukan analisis terhadap wujud ancaman dan kesempatan agar dapat membedakan keadaan lingkungan yang akan datang sehingga dapat ditemukan masalah yang ada (Anton,2021). Untuk menunjang strategi-strategi tersebut, diperlukan cara atau strategi representatif dan solutif yang mencerminkan kepemimpinan digital untuk menyelesaikan berbagai hambatan dan mengoptimalkan potensi yang ada. Identifikasi dan perumusan strategi yang relevan dan tepat sasaran perlu memperhatikan berbagai faktor yang berpengaruh dalam implementasi digital leadership. Konsep kepemimpinan gaya baru tersebut dapat membawa generasi yang berbeda dari anggotanya untuk bekerja sama secara kolaboratif. Konsep digital melayani telah mulai diterapkan pada pelayanan perijinan frekuensi radio dengan makin bertambahnya pengguna frekuensi yang jumlahnya mencapai hampir 500ribu (Ditjen SDPPI,2019) walaupun masih terdapat kendala dalam pelaksanaannya, dan perlu terus meningkatkan kompetensi digital bagi para anggotanya. Kelebihan pada penelitian ini adalah yang pertama kali mengangkat masalah digital leadership kaitannya dengan pelayanan publik serta kompetensi sumber daya manusia yang bertugas dibidang pelayanan perizinan frekuensi radio. Keterbatasan studi ini karena hanya mencakup pada area kepemimpinan dan pelayanan publik saja sehingga bisa diperluas ke area lainnya, yaitu bisnis proses dan regulasi, tata kelola dan kelembagaan, customer engagement, dan inovasi.

Analisis SWOT merupakan bagian dari tahap perencanaan strategi suatu organisasi yang terdiri dari tiga tahap: tahap pengumpulan data, tahap analisis, dan tahap pengambilan keputusan (Haudi, 2021). Faktor-faktor potensi/kekuatan (strength), kelemahan (weakness), kesempatan (opportunity) dan tantangan (threat) pada implementasi digital leadership dalam pengembangan kompetensi digital pada pelayanan publik Ditjen SDPPI sebagaimana pada matrik analisis SWOT pada Gambar 3.

Memperhatikan analisis SWOT tersebut, didapat hasil analisis dari empat faktor yang berbeda, yaitu 1) Analisis kekuatan (strength) yaitu situasi atau kondisi yang merupakan kekuatan organisasi untuk dimanfaatkan mengisi peluang (opportunity) yang ada; 2) Untuk analisis kelemahan (weakness) dalam suatu organisasi bagaimana mengatasi kelemahan atau kendala serius; 3). Kekuatan (strength) mampu menghadapi ancaman (threats) yang ada; 4) Analisis kelemahan (weakness) yang berpotensi menjadi ancaman (threats) dan bisa menjadi ancaman baru.

Penerapan teori dalam penulisan karya tulis ini adalah kekuatan yang berasal dari karakteristis pemimpin digital dalam mengatur timnya dan mengatasi kelemahan yang ada dan untuk memanfaatkan peluang yang tersedia. Diharapkan penerapan strategi berjalan dengan baik dengan selalu mengoptimalkan kekuatan dalam menghadapi ancaman yang setiap saat terjadi. 


\begin{tabular}{|c|c|c|}
\hline Eksternal & $\begin{array}{l}\text { Strength: } \\
\text { - Pemimpin matang dalam Literasi } \\
\text { Digital } \\
\text { - } \text { Tersedia visi dan strategi digital } \\
\text { - Pemimpin selalu mengutamakan } \\
\text { komunikasi dan kolaborasi } \\
\text { dalam memecahkan } \\
\text { permasalahan dan pencapaian } \\
\text { target serta berpartisipasi } \\
\text { membangun ekosistem capaian } \\
\text { tujuan organisasi }\end{array}$ & \begin{tabular}{l}
\multicolumn{2}{c}{ Weakness: } \\
- Kurangnya internalisasi \\
pemahaman persyaratan dan \\
prosedur bagi petugas. \\
- Managemen belum sepenuhnya \\
meng-upgrade sistem \\
- Manajemen belum mengatur \\
waktu permohonan izin diluar \\
jam kerja \\
- Belum adanya tracking \\
penyelesaian pengaduan \\
- Roadmap pengembangan \\
kompetensi SDM belum \\
tersedia.
\end{tabular} \\
\hline $\begin{array}{l}\quad \text { Opportunity } \\
\text { - } \\
\text { Kebijakan Pemeritah Digital } \\
\text { Melayani dan RB } \\
\text { - } \\
\text { Animo masyarakat pengguna } \\
\text { frekuensi tinggi } \\
\text { - } \\
\text { Kesempatan mengembangkan } \\
\text { daerah 3T tinggi akan } \\
\text { kebutuhan internet. } \\
\text { - }\end{array}$ & 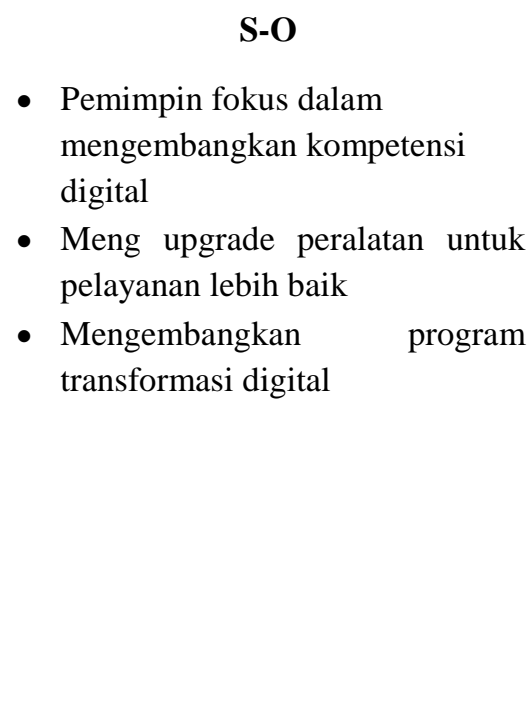 & $\begin{array}{l}\text { W-O } \\
\text { - Mengoptimalkan internalisasi } \\
\text { koordinator pelayanan untuk } \\
\text { pemahaman prosedur dan } \\
\text { persyaratan perizinan SFR. } \\
\text { - Mengembangkan sistem untuk } \\
\text { menunjang pelayanan publik } \\
\text { - Memastikan ketersediaan } \\
\text { frekuensi atas makin } \\
\text { bertambahnya animo masyarakat } \\
\text { pengguna frekuensi } \\
\text { - Mengoptimalkan penggunaan } \\
\text { anggaran untuk pengembangan } \\
\text { kompetensi SDM secara } \\
\text { tersistem }\end{array}$ \\
\hline $\begin{array}{l}\text { Threat: } \\
\text { - Tuntutan masyarakat akan } \\
\text { pelayanan cepat, murah dan } \\
\text { transparan } \\
\text { - Revolusi Industri } 4.0 \\
\text { - Kemajuan teknologi yg sangat } \\
\text { cepat } \\
\text { - Keamanan data } \\
\text { - Potensi waba tidak memenuhi } \\
\text { kewajiban }\end{array}$ & $\begin{array}{l}\text { - } \text { Mengembangkan kapasitas } \\
\text { kompetensi digital para } \\
\text { koordinator dan anggota secara } \\
\text { terprogram } \\
\text { - } \text { Mengembangkan keamanan data } \\
\text { sesuai roadmap } \\
\text { - } \text { Mengoptimalkan pendapatan } \\
\text { PNBP sesuai ketentuan }\end{array}$ & $\begin{array}{l}\text { W-T } \\
\text { - } \text { Meningkatkan internalisasi } \\
\text { manajemen pemahaman } \\
\text { prosedur dan persyaratan bagi } \\
\text { koordinator dan petugas } \\
\text { - Mengembangkan sistem } \\
\text { - Membangun sistem tracking } \\
\text { penyelesaian pengaduan } \\
\text { - Menyiapkan analisis dan } \\
\text { roadmap pengembangan } \\
\text { kompetensi pelayanan digital }\end{array}$ \\
\hline
\end{tabular}

Sumber: Olahan Data

Gambar 3. Matrik SWOT Implementasi Digital Leadership Dalam Pengembangan Kompetensi Digital Pada Pelayanan Publik Ditjen SDPPI 


\section{PENUTUP}

Setelah melakukan eksplorasi dari beragam literatur, data, dokumen dan pembahasan dalam Focus Group Discusion, implementasi digital leadership memberikan kekuatan pada kebijakan pimpinan dalam mengatur pemanfaatan teknologi informasi untuk memecahkan permasalahan secara kolaboratif dan dengan komunikasi yang efektif antara pimpinan dan anggotanya. Penelitian ini menyimpulkan bahwa hambatan-hambatan dan kendala yang ditemui dalam pelayanan perlu segera diatasi dengan pengembangan program transformasi digital untuk meningkatkan kualitas pelayanan publik perizinan spektrum frekuensi radio. Karena perkembangan teknologi digital sangat cepat, perlu diantisipasi dalam mengembangan kapasitas kompetensi digital bagi para coordinator dan anggota secara terprogram, terencana, dan terukur. Selain hal tersebut, tidak kalah pentingnya adalah adanya pemahaman literasi digital yang matang dari pimpinan dan para koordinator serta menghasilkan pengembangan program transformasi digital untuk meningkatkan pelayanan publik spektrum frekuensi radio terwujud walaupun masih dalam tahap awal. Penerapan strategi mengembangkan kapasitas kompetensi digital bagi para koordinator dan anggota secara terprogram, terencana, dan terukur menjadi sangat penting. Di samping itu perlu meningkatkan internalisasi manajemen dalam rangka pemahaman prosedur, persyaratan yang bersifat teknis bagi koordinator dan petugas pelayanan publik.

Kelanjutan dari studi ini adalah penelitian dengan penggunaan metode statistik dalam hal menajemen frekuensi radio ditinjau dari sudut pandang transformasi digital dapat dilakukan. Hal ini akan membantu mempersiapkan organisasi dalam pelayanan yang lebih baik dan program pengembangan kompetensi ASN di bidang frekuensi radio yang tidak banyak jumlahnya

\section{Ucapan Terima Kasih}

Dengan telah selesainya penulisan artikel ilmiah ini, saya mengucapkan banyak terima kasih kepada penerbit jurnal, para sahabat dan teman sejawat, para reviewer serta semua pihak yang telah membantu, memberikan pandangan, saran, dan kritik untuk terwujudnya tulisan artikel ilmiah saya ini.

\section{DAFTAR PUSTAKA}

Anh, N. V. (2015). Factors Affecting Effective Leadership. Proceeding of the Second Asia-Pacific Conferenc on Global Business, Economics, Finance and Social Science.

Chodhary, N., Kumar, R., \& Philip, P. . (2015). Leadership Effectiveness, Organizational Citizenship Behavior and Task Performance: The Role of Job Characteristics at the Work place. MAnagement Journal, 13(5), 3433-3448.

Cordella, A., \& Tempini, N. (2015). E-government and Organizational change: Reappraising the role of ICT and bereaucracy in public service delivery.

DR.Ismail. (2020). Akselerasi Transformation Digital. Bisnis Indonesia.

Dronamraju, D. (2018). Process Improvement Strategy for Public Sector Organizations. Linkoping University.

Gallardo, E. E., \& Minelli de Oliveira, J. (2015). Digital Competence in The Knowledge Society. Journal of Online Learning and Teaching, 11 (Education).

Gurel, E., \& TAT, M. (2017). SWOT ANALYSIS: A Theoretical Review. The Journal of International Social Research, 10(51).

Haudi. (2021). Teknik Pengambilan Keputusan (H. Wijoyo (ed.); Pertama). Insan Cendekia Mandiri. www.insancendikiamandiri.com

Hoerudin, C. W. (2020). Adaptive Leadership in Digital Era. Jurnal Ilmu Pemerintahan, 6(1).

Dwi Hadya Jayani(2019). Indonesia Peringkat Kelima Terendah di Asean dalam Kemudahan Bisnis . Retrieved 4 Mei 2021, from https://databoks.katadata.co.id/datapublish/2019/10/25/indonesiaperingkat-kelima-terendah-di-asean-dalam-kemudahan-bisnis 
Jarad, G. A., \& Shaalan, M. A. (2020). Assessment of Digital Competence of Employees and Teaching Staff at The Technical College of Management Kufa. International Journal of Innovation, Creativity and Change, 12(12), 1-17.

John W, C. (2017). Penelitian Kualitatif (S. Quddsy (ed.); 3rd ed.). Pustaka Pelajar.

Kazim, F. A. (2019). Digital Transformation and Leadership Style : A Multiple Case Study. The ISM Journal of International Business, 3(1), 28.

Klein, M. (2020). Leadership Characteristics in The Era of Digital Transformation. Business\&Management Studies: An International Journal, 8(1), 883-902.

Mardalena. (2017). Efektifitas Kepemimpinan. Journal of Management, 2.

Moleong, P. D. L. J. (2017). Metodologi Penelitian Kualitatif. PT.Remaja Rosdakarya.

Narbona, J. (2016). Digital leadership,twitter and pope Francis. 1, 90-109.

Oberer,B,\& Erkollar, A. (2018). Digital Leaders in the Age. International Journal of Organizational Leadership, 7404, 404-412.

Rahardjo, M. (2017). Studi Kasus Dalam Penelitian Kualitatif. Вестник Росздравнадзора, 4, 9-15. https://doaj.org/article/f820bd6e28cf44988e96d72e946a06ff

Setiadi, R., Adawiyah, E. R., \& Sumarna, A. (2020). Buku Ajar Manajemen Strategik (Khaeruman (ed.); Pertama). CV.AA.Rizky. www.aarizky.com

Sullivan, L. (2017). Skills Every Digital Leader Needs. https://www.cmswire.com/digital-workplace/8-skillsevery-digital-leader-needs/ 